\title{
Long Beach Transit: Two-Year Evaluation of Gasoline-Electric Hybrid Transit Buses
}

\section{Technical Report} NREL/TP-540-42226 June 2008

\author{
M. Lammert
}

National Renewable Energy Laboratory 


\section{Long Beach Transit: Two-Year Evaluation of Gasoline-Electric Hybrid Transit Buses}

Technical Report NREL/TP-540-42226 June 2008

M. Lammert

National Renewable Energy Laboratory

Prepared under Task No(s). FC08.3000

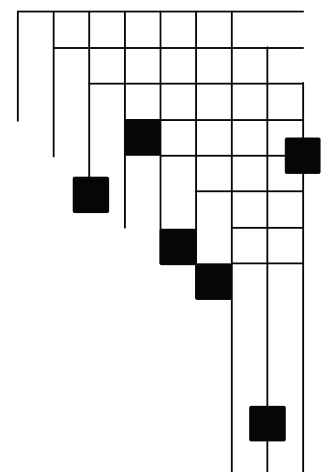




\section{NOTICE}

This report was prepared as an account of work sponsored by an agency of the United States government. Neither the United States government nor any agency thereof, nor any of their employees, makes any warranty, express or implied, or assumes any legal liability or responsibility for the accuracy, completeness, or usefulness of any information, apparatus, product, or process disclosed, or represents that its use would not infringe privately owned rights. Reference herein to any specific commercial product, process, or service by trade name, trademark, manufacturer, or otherwise does not necessarily constitute or imply its endorsement, recommendation, or favoring by the United States government or any agency thereof. The views and opinions of authors expressed herein do not necessarily state or reflect those of the United States government or any agency thereof.

Available electronically at http://www.osti.gov/bridge

Available for a processing fee to U.S. Department of Energy and its contractors, in paper, from:

U.S. Department of Energy

Office of Scientific and Technical Information

P.O. Box 62

Oak Ridge, TN 37831-0062

phone: 865.576.8401

fax: 865.576 .5728

email: mailto:reports@adonis.osti.gov

Available for sale to the public, in paper, from:

U.S. Department of Commerce

National Technical Information Service

5285 Port Royal Road

Springfield, VA 22161

phone: 800.553 .6847

fax: 703.605.6900

email: orders@ntis.fedworld.gov

online ordering: http://www.ntis.gov/ordering.htm 


\title{
Acknowledgments
}

This evaluation is funded through the Advanced Vehicle Testing Activity, which is managed by Lee Slezak within the U.S. Department of Energy (DOE). All publications on the Long Beach Transit (LBT) hybrid bus evaluation will be posted on DOE's Energy Efficiency and Renewable Energy Web site. See the Medium- \& Heavy-Duty Vehicles section of the following link: http://www1.eere.energy.gov/vehiclesandfuels/avta/index.html.

This evaluation at LBT would not have been possible without the support and cooperation of many people. The author wishes to thank each of the following:

\author{
Lee Slezak \\ Long Beach Transit \\ James Ditch \\ Rolando Cruz \\ Bryan Mills
}

U.S. Department of Energy

ISE Corporation

Tom Bartley

Joshua Goldman

Harry Meyer

Battelle

Kevin Chandler 


\section{List of Acronyms}

AVTA-Advanced Vehicle Testing Activity

bhp-brake horsepower

CARB - California Air Resources Board

DOE-U.S. Department of Energy

EGR - exhaust gas recirculation

FT\&E—Fleet Test and Evaluation (NREL team)

$\mathrm{g} /$ bhp-hr- grams per brake horsepower hour

GVWR — gross vehicle weight rating

HVAC - heating, ventilation, and air conditioning

LBT-Long Beach Transit

MBRC - miles between road calls

mph-miles per hour

MY - model year

$\mathrm{NO}_{\mathrm{x}}$ - oxides of nitrogen

NREL - National Renewable Energy Laboratory

PM-particulate matter

ppm-parts per million

$\mathrm{RC}$ - road call

rpm-revolutions per minute

SCAQMD—South Coast Air Quality Management District

ULSD - ultra-low sulfur diesel

VDC—voltage direct current 


\section{Executive Summary}

This report is part of a series of evaluations from the U.S. Department of Energy (DOE). DOE, through the National Renewable Energy Laboratory (NREL), has been tracking and evaluating new propulsion systems in transit buses and trucks for more than 10 years using an established and documented evaluation protocol. The DOE/NREL vehicle evaluations are a part of the Advanced Vehicle Testing Activity (AVTA), which supports DOE's Vehicle Technologies Program.

The role of AVTA is to bridge the gap between research and development and commercial availability of advanced vehicle technologies that reduce petroleum use in the U.S. while improving air quality. The main objective of AVTA projects is to provide comprehensive, unbiased evaluations of advanced vehicle technologies in commercial use. Data are collected and analyzed for operation, maintenance, performance, cost, and emissions characteristics of advanced technology fleets and comparable conventional technology fleets operating at the same site. By comparing available advanced and conventional technology vehicles, AVTA evaluations help fleet owners and operators make informed purchasing decisions.

This report focuses on a gasoline-electric hybrid transit bus propulsion system. This propulsion system is an alternative to standard diesel buses and allows for reductions in emissions (usually focused on reductions of particulate matter and oxides of nitrogen) and petroleum use. Gasoline propulsion is an alternative to diesel fuel and hybrid propulsion allows for increased fuel economy, which ultimately results in reduced petroleum use.

\section{Evaluation Design}

This report describes the evaluation results for New Flyer low floor buses with new gasoline hybrid propulsion (equipped with ISE Corporation's ThunderVolt Hybrid Drive propulsion system) and older diesel buses at the Long Beach Transit (LBT). These final results represent a 24-month evaluation (July 2005 through June 2007)of these two groups of buses.

The evaluation team selected 10 vehicles from the hybrid group of 47 vehicles and 10 vehicles from the diesel group of 138 vehicles for analysis. The number of vehicles that comprise the study was determined sufficient to provide some degree of statistical significance to the results obtained.

\section{Evaluation Results}

The following results and related discussions focus only on selected operating depots and the two study bus groups.

\section{Bus Use and Duty Cycle}

LBT operates 228 buses out of two facilities and averages almost 40,000 miles per bus annually for both facilities. The average speed of the 40 - $\mathrm{ft}$ bus fleet is 13.8 miles per hour (mph) with an average of 8 stops per mile. LBT currently has forty-seven 40-ft hybrid gasoline-electric buses. The hybrid study group had a usage rate of 31,875 miles per 
month $(38,250$ miles per bus annually) $-2.4 \%$ lower than that of the diesel study group buses. This small difference is not statistically significant and makes the two groups ideal for comparison.

\section{Fuel Economy and Fuel Costs}

On a volumetric basis, the 24-month average fuel economy for the hybrid buses is 3.35 miles per gallon (mpg) $-4.3 \%$ lower than that of the diesel buses. This difference is likely due to the lower efficiency of a throttled, spark-ignited engine as well as the lower energy content of a gallon of gasoline versus a gallon of diesel. On an equivalent energy per volume basis, the hybrids had an $8.5 \% \mathrm{mpg}$ increase. During the evaluation period, gasoline at LBT cost an average of $\$ 2.49$ per gallon and diesel cost an average of $\$ 2.29$ per gallon. This lower fuel economy, combined with a higher fuel cost for gasoline, resulted in fuel costs per mile being $\$ .74$ per mile for the hybrids as compared to $\$ .65$ per mile for the diesels.

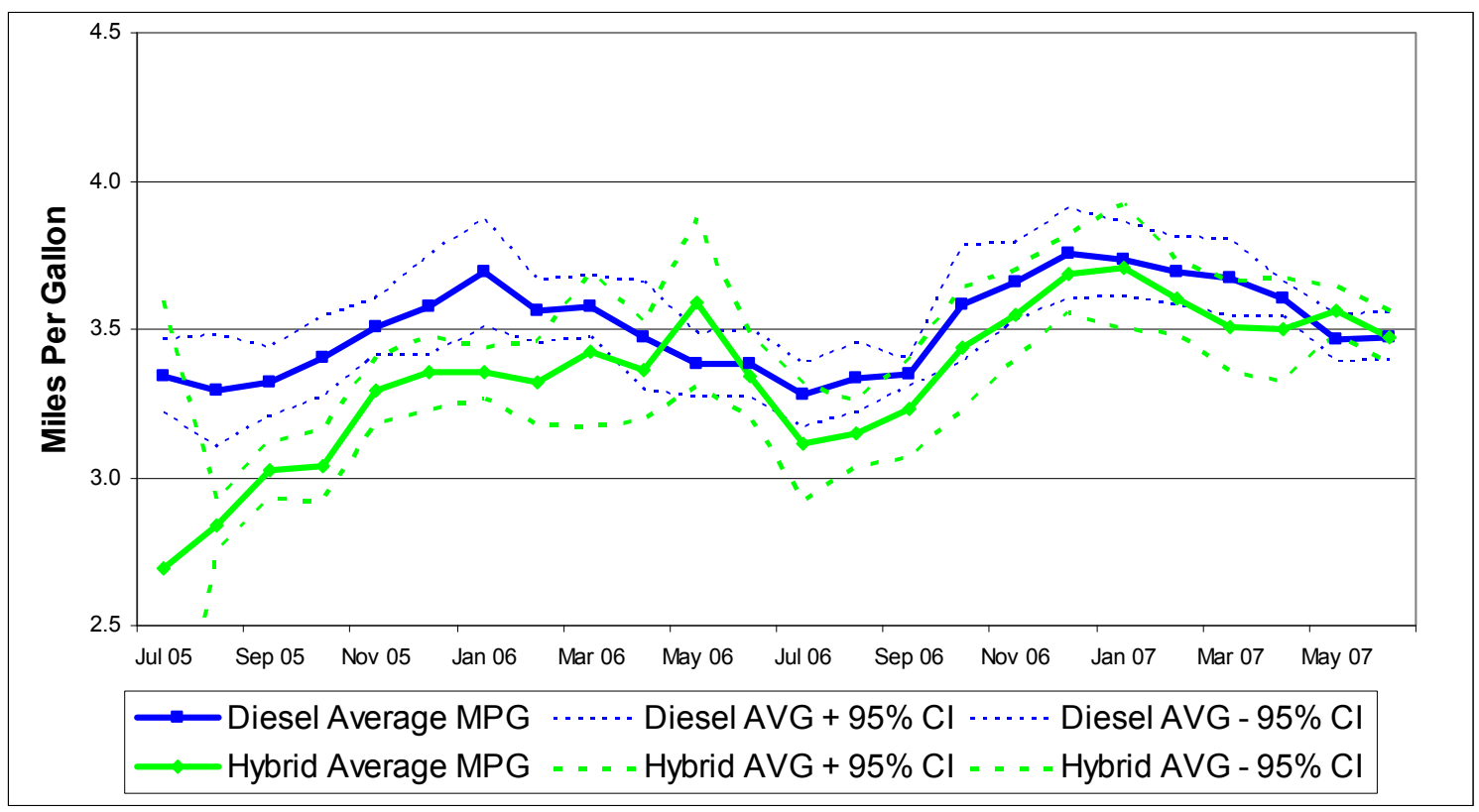

Figure ES-1. Average Monthly Fuel Economy

\section{Maintenance Costs}

At the beginning of the evaluation period, the hybrid buses were brand new and remained under warranty for the evaluation period, which accounts for the cost-per-mile difference with the older, out-of-warranty diesel buses. The hybrids cost $\$ .31$ per mile to maintain while the diesels cost $\$ .54$ per mile. Propulsion related costs were $\$ .08$ per mile for the hybrids and $\$ .19$ per mile for the diesels.

\section{Brake System Related Maintenance Costs}

In general, the brake system maintenance costs are expected to be dramatically lower for hybrid propulsion systems with regenerative braking, which allows use of the electric drive motors to slow a bus, similar to a transmission retarder. The energy from braking is taken into the electric motor and then fed back to the ultra-capacitors. The hybrids had 
brake system maintenance costs that were about $90 \%$ less than that of the diesel buses with no relines to date on the hybrids.

\section{Ultra-Capacitors}

LBT chose to use ultra-capacitors for energy storage instead of the traction batteries more commonly used in hybrid transit buses. The ultra-capacitors work well for LBT's duty cycle with frequent stops per mile and slow average speeds and are able to take advantage of the high charge and discharge rates associated with the frequent starts and regenerative braking events. In addition, the ultra-capacitors have a 12-year life expectancy compared to three to six years for batteries. ISE offers a three-year extended warranty on top of their two-year standard warranty for the ultra-capacitors.

During the evaluation period a manufacturing issue was identified; acetonitrile was leaking from some of the ultra-capacitors. ISE corrected the issue with a warranty campaign based on serial numbers of suspect batches of ultra-capacitors.

\section{Road Calls}

In this report, a road call (RC) is defined as an on-road failure of an in-service bus, which results in a bus being taken out of service or replaced on-route. RCs are a direct indicator of reliability for transit buses. Miles between RC (MBRC) is a typical industry measurement for RC performance for transit buses. The hybrid buses had 9,000 MBRC compared to the diesel buses with just above 11,000 .

For RCs related only to the propulsion system, the hybrid buses are 15,000 MBRC. For comparison, the older diesel buses have MBRC at just above 19,000. 


\section{Table of Contents}

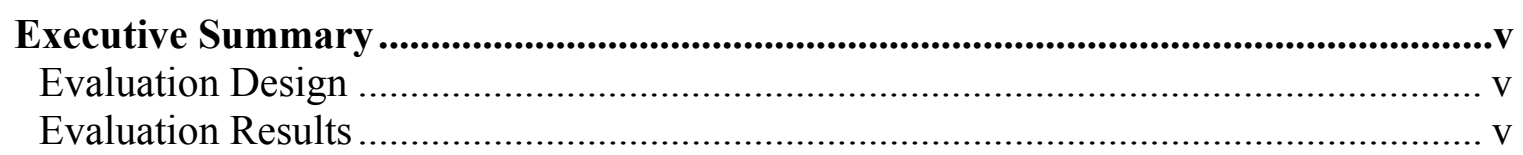

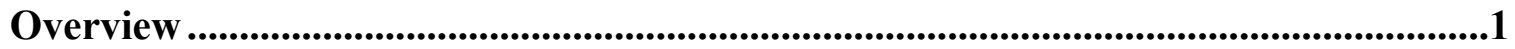

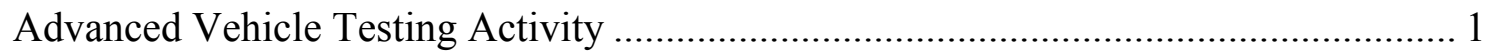

Host Site Profile_-Long Beach Transit.................................................................. 2

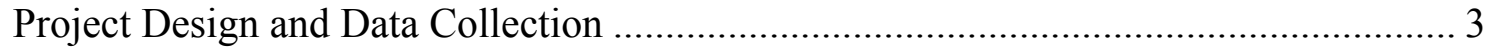

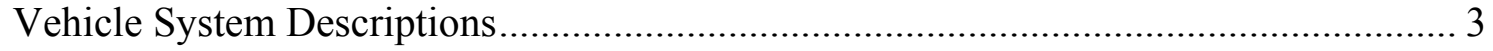

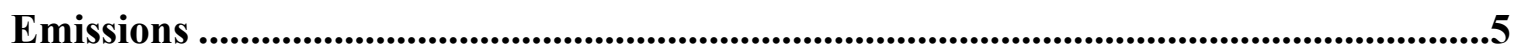

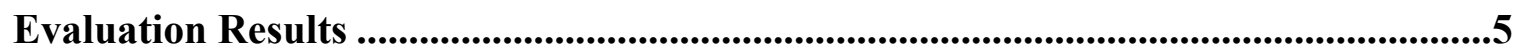

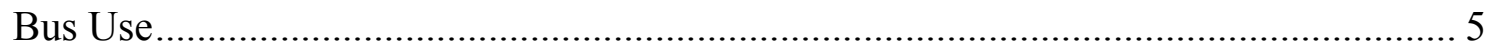

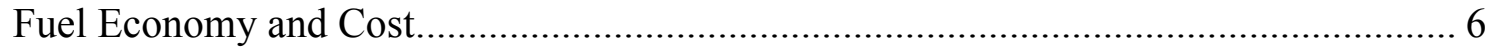

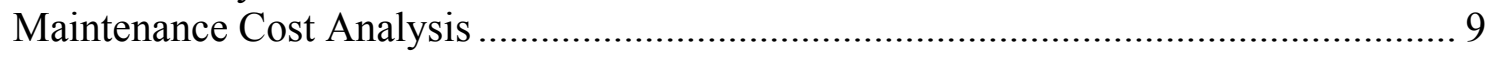

Total Maintenance Costs ................................................................................... 10

Propulsion-Related Maintenance Costs ............................................................. 10

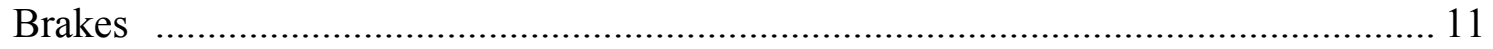

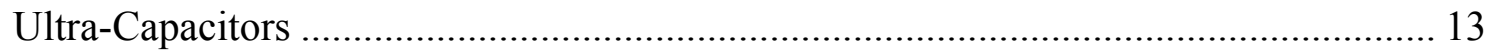

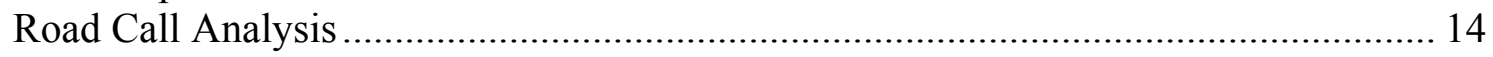

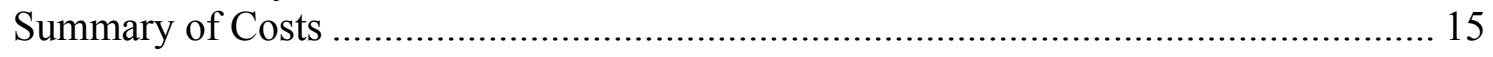

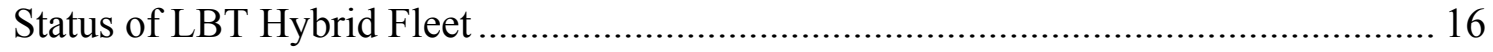

References and Related Reports...................................................................18 


\section{Overview}

\section{Advanced Vehicle Testing Activity}

The role of the Advanced Vehicle Testing Activity (AVTA) is to help bridge the gap between research and development (R\&D) and commercial availability for advanced vehicle technologies that reduce petroleum use while meeting air quality standards. AVTA supports the Department of Energy's (DOE) Vehicle Technologies Program by examining market factors and customer requirements and evaluating the performance and durability of alternative fuel and advanced technology vehicles in fleet applications. The National Renewable Energy Laboratory's (NREL) Fleet Test and Evaluation (FT\&E) team conducts evaluations primarily under support from AVTA, but also under support from other DOE programs focused on nonpetroleum-based and advanced petroleum-based fuels.

The main objective of FT\&E projects is to conduct comprehensive, unbiased evaluations of advanced technology vehicles. Data collected and analyzed include the operations, maintenance, performance, cost, and emissions characteristics of advanced technology vehicles and comparable conventional technology in fleets operating at the same site. By comparing available advanced and conventional technology vehicles, FT\&E evaluations help fleet owners and operators make informed purchasing decisions. The evaluations also provide valuable data to DOE about the maturity of the technology being assessed.

The FT\&E team recently conducted —or is in the process of conducting - several evaluations of advanced propulsion heavy-duty vehicles (see Table 1). For information on these and other evaluations involving advanced technologies or alternative fuels such as biodiesel and Fischer-Tropsch diesel, visit www.nrel.gov/vehiclesandfuels/fleettest.

Table 1. FT\&E Heavy-Duty Vehicle Evaluations

\begin{tabular}{|c|c|c|c|c|}
\hline Fleet & Location & Vehicle & Technology & Evaluation Status \\
\hline Metro & St. Louis, MO & $\begin{array}{l}\text { GILLIG 40-ft } \\
\text { transit bus }\end{array}$ & Biodiesel blend (B20) & $\begin{array}{l}\text { In progress; interim } \\
\text { report completed } \\
\text { Nov. 2007; final } \\
\text { report in June } 2008\end{array}$ \\
\hline $\begin{array}{l}\text { New York City } \\
\text { Transit }\end{array}$ & $\begin{array}{l}\text { Manhattan, } \\
\text { Bronx, NY }\end{array}$ & $\begin{array}{l}\text { Orion VII } 40-\mathrm{ft} \\
\text { transit bus }\end{array}$ & $\begin{array}{l}\text { Series hybrid, BAE Systems } \\
\text { HybriDrive propulsion system } \\
\text { (diesel), Order of } 200 \text { (Gen II); } \\
\text { Order of } 125 \text { (Gen I); }\end{array}$ & $\begin{array}{l}\text { Completed in Jan. } \\
2008\end{array}$ \\
\hline $\begin{array}{l}\text { New York City } \\
\text { Transit }\end{array}$ & $\begin{array}{l}\text { Manhattan, } \\
\text { Bronx, NY }\end{array}$ & $\begin{array}{l}\text { Orion VII } 40-\mathrm{ft} \\
\text { transit bus }\end{array}$ & $\begin{array}{l}\text { Series hybrid, BAE Systems } \\
\text { HybridDrive propulsion system } \\
\text { (diesel), order of 125; DDC } \\
\text { S50G CNG engines }\end{array}$ & $\begin{array}{l}\text { Completed in Nov. } \\
2006\end{array}$ \\
\hline Denver RTD & Boulder, CO & $\begin{array}{l}\text { GILLIG } 40-\mathrm{ft} \\
\text { transit bus }\end{array}$ & Biodiesel blend (B20) & $\begin{array}{l}\text { Completed in Oct. } \\
2006\end{array}$ \\
\hline $\begin{array}{l}\text { King County } \\
\text { Metro }\end{array}$ & Seattle, WA & $\begin{array}{l}\text { New Flyer 60-ft } \\
\text { articulated } \\
\text { transit bus }\end{array}$ & $\begin{array}{l}\text { Parallel hybrid, GM-Allison } \\
E^{P} 50 \text { System (diesel) }\end{array}$ & $\begin{array}{l}\text { Completed in Dec. } \\
2006\end{array}$ \\
\hline IndyGo & Indianapolis, IN & Ebus 22-ft bus & $\begin{array}{l}\text { Series hybrid, Capstone } \\
\text { MicroTurbine (diesel) }\end{array}$ & Completed in 2005 \\
\hline $\begin{array}{l}\text { Knoxville Area } \\
\text { Transit }\end{array}$ & Knoxville, TN & Ebus 22-ft bus & $\begin{array}{l}\text { Series hybrid, Capstone } \\
\text { MicroTurbine (propane) }\end{array}$ & Completed in 2005 \\
\hline Norcal & $\begin{array}{l}\text { San Francisco, } \\
\text { CA }\end{array}$ & $\begin{array}{l}\text { Peterbilt/378, } \\
\text { Class } 8 \text { truck }\end{array}$ & $\begin{array}{l}\text { Cummins Westport ISXG high- } \\
\text { pressure, direct- injection, } \\
\text { liquefied natural gas (LNG) and } \\
\text { diesel }\end{array}$ & Completed in 2004 \\
\hline
\end{tabular}




\section{Host Site Profile-Long Beach Transit}

Long Beach Transit (LBT) operates 228 buses out of two facilities: Anaheim and Larry Jackson, which are located only seven miles apart. The fleet is made up of thirty $30-\mathrm{ft}$ buses, one hundred and eightyfive 40-ft buses, and thirteen articulated buses. LBT services seven cities, transports 28-29 million passengers per year, and averages almost 40,000 miles per bus annually. The average speed of the $40-\mathrm{ft}$ bus fleet is 13.8 miles per hour ( $\mathrm{mph}$ ) with an average of eight stops per mile. LBT currently has fortyseven 40-ft hybrid gasoline-electric buses that arrived in June through August of 2005. The transit authority has taken delivery of 15 more in the third quarter of 2007 and has requested an additional 25 for 2008 .

Because LBT operates in the South Coast Air Quality Management District (SCAQMD), SCAQMD regulations prevented LBT from purchasing new diesel buses after 2002. As in other California transit districts, the primary path toward reducing oxides of nitrogen (NOx) and particulate matter (PM) emissions had been using buses powered by natural gas. LBT conducted an overall cost analysis, though, that led the agency to try the new hybrid gasoline-electric buses instead. Like natural gas, gasoline was qualified as an alternative fuel for transit buses by the California Air Resources Board (CARB).

LBT's cost analysis showed that the hybrids would be more cost-effective than buses powered by natural gas in terms of capital costs for infrastructure, better fuel economy, and savings in maintenance on brake relines and transmission overhauls. In addition, replacing the gasoline engine would be less expensive than overhauling a diesel engine. LBT already had gasoline fueling capability on site, so for the first year of operation the new hybrid gasoline-electric buses used the existing facility. After the first year, LBT spent \$1.9 million to upgrade its facilities to update the fuel island at one of the properties with new lines, replace aging fuel tanks, and expand the gasoline capacity for future growth. The second facility required no changes.

Combining a light-duty gasoline engine in a series hybrid heavy-duty application with ultra-capacitors had never been done before. LBT had no official expectations for the hybrids in regards to reliability and durability, but did expect to have some growing pains with the new technology. The hybrids (see Figure 1) were put into service and dispatched the same as the diesel buses with the exception of a few highspeed routes.

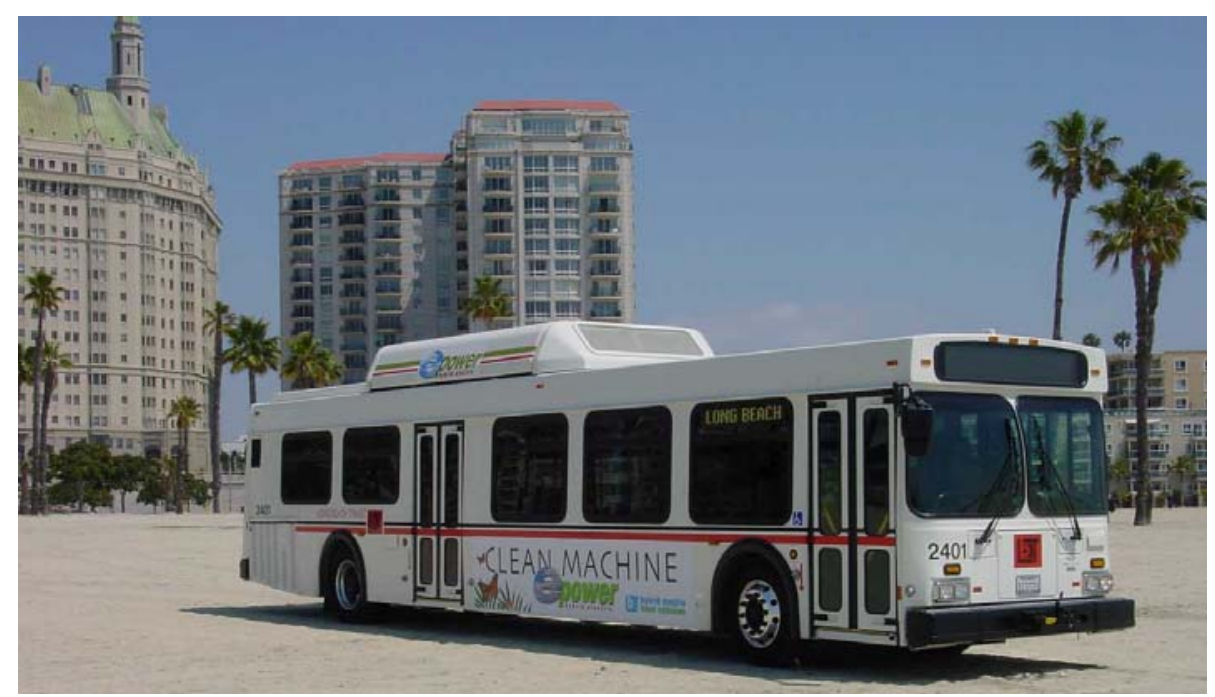

Figure 1. Photo of one of LBT's gasoline-electric hybrid transit buses. 


\section{Project Design and Data Collection}

In this evaluation, the focus is on the hybrids purchased in model year (MY) 2004 and 2005 by LBT and their performance during the first 2 years of service (7/05/05 -6/07/07). MY 2002 diesel buses are used as a baseline in this evaluation.

Two major interests in hybrid bus operations held by the transit industry are (1) determining energy storage replacement frequency and costs, and (2) quantifying the benefits of regenerative braking, realized in reduced brake system maintenance costs.

Ten hybrid buses and 10 diesel buses (MY 2002) were randomly chosen for this evaluation. The buses were spread evenly between the Anaheim and Larry Jackson depots. The depots both dispatch to all routes that LBT services and the study buses were assigned to routes randomly with the normal fleet of 40 -ft buses. The preventive maintenance schedules and maintenance practices are the same at each depot.

Vehicle-specific data for this evaluation were taken from LBT's maintenance and fueling data system. The evaluation period for buses considered in this report began in July 2005 and ended in June 2007.

Data parameters included the following:

- Diesel and gasoline fuel consumption

- Mileage accumulation

- Maintenance records, including work orders, parts costs, and labor hours

- Road call (RC) records.

\section{Vehicle System Descriptions}

LBT's hybrid buses are built by New Flyer and use the ISE Corporation's ThunderVolt series Hybrid Drive propulsion system (Figure 2).

\section{HYBRID ENERGY FLOW}

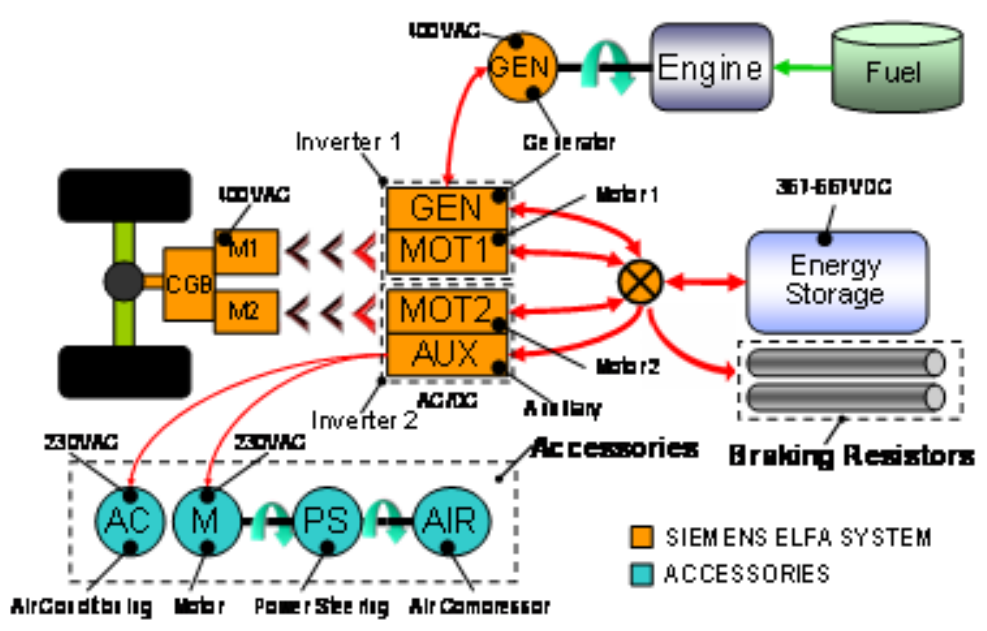

Figure 2. Schematic of ThunderVolt series hybrid drive propulsion system. 
In this series hybrid electric system, a Ford 6.8 L Triton V-10 gasoline engine is connected to a generator that produces electricity for the electric drive motor and the ultra-capacitors. The electric motor drives the vehicle and acts as a generator that captures energy during regenerative braking. The electrolytic ultra-capacitors supplied by Maxwell supply additional power during acceleration and hill climbing and store energy recovered during regenerative braking and idling.

Table 2 presents additional details on the hybrid system and Table 3 provides brief descriptions of the vehicle systems.

Table 2. Hybrid Propulsion-Related Systems

\begin{tabular}{|l|l|}
\hline \multicolumn{1}{|c|}{ Category } & \multicolumn{1}{|c|}{ Hybrid Bus Description } \\
\hline Manufacturer/integrator & ISE Corporation, ThunderVolt Hybrid Drive propulsion \\
& system \\
\hline Combining Gearbox & 2 AC motor input \\
& Peak input torque: $2 \times 600 \mathrm{Nm}$ \\
& Peak output torque: $4860 \mathrm{Nm}$ \\
& Max input speed: $10,000 \mathrm{rpm}$ \\
& Ratio: 4.05 \\
& Weight: $100 \mathrm{~kg}$ \\
\hline Motor & Type: 3-Phase Asynchronous Motor \\
& Nominal power: $85 \mathrm{~kW}$ \\
& Peak power: $150 \mathrm{~kW}$ \\
& Nominal torque: $220 \mathrm{Nm}$ \\
& Peak torque: $530 \mathrm{Nm}$ \\
& Rated voltage DC: $650 \mathrm{~V}$ \\
& Nominal current: $142 \mathrm{~A}$ \\
& Peak current: $250 \mathrm{~A}$ \\
\hline Generator & Type: Permanent Magnet Sync. \\
& Nominal power: $110 \mathrm{~kW}$ \\
& Peak power: $145 \mathrm{~kW}$ \\
& Nominal torque: $320 \mathrm{Nm}$ \\
& Peak torque: $450 \mathrm{Nm}$ \\
& Rated voltage DC: $650 \mathrm{~V}$ \\
& Rated current: $170 \mathrm{~A}$ \\
& Weight: $120 \mathrm{~kg}$ \\
\hline Braking Resistors & Type: Ultra-capacitor, Maxwell Boostcap \\
& 2 enclosures, $144 \mathrm{capacitors}$ each, \\
& Roof mounted \\
& Voltage per enclosure: 360 VDC rated; $403 \mathrm{VDC}$ peak \\
& Weight per enclosure: $100 \mathrm{~kg}$ \\
\hline Energy storage & Two units in parallel configuration \\
& Capacity: 2 x $60 \mathrm{~kW}$ continuous \\
& Capacity: $2 \mathrm{x} 70 \mathrm{~kW}$ max for 15 seconds \\
\hline
\end{tabular}


Table 3. Vehicle System Descriptions

\begin{tabular}{|l|l|l|}
\hline \multicolumn{1}{|c|}{ Bus Specification } & \multicolumn{1}{|c|}{$\begin{array}{c}\text { Hybrid Gasoline-Electric } \\
\text { Buses }\end{array}$} & \multicolumn{1}{c|}{ Diesel Buses } \\
\hline Bus manufacturer & New Flyer & New Flyer \\
\hline Bus model & low-floor GE40LF & low-floor D40LF \\
\hline Model year & 2004 and 2005 & 2002 \\
\hline Length/width/height & $40.8 \mathrm{ft} / 102$ in./136 in. & $40.8 \mathrm{ft} / 102 \mathrm{in} . / 110.4 \mathrm{in}$. \\
\hline $\begin{array}{l}\text { Gross vehicle weight rating } \\
\text { (GVWR)/curb weight }\end{array}$ & $40,130 / 26,800 \mathrm{lb}$ & $37,920 / 26,800 \mathrm{lb}$ \\
\hline Passenger capacity & 38 seated, 19 standing & 38 seated, 19 standing \\
\hline Engine manufacturer and model & Ford 2004 Triton V-10 & $\begin{array}{l}\text { Cummins ISC (diesel particulate } \\
\text { filter equipped) }\end{array}$ \\
\hline Rated horsepower & 305 bhp @ 4,250 rpm & 280 bhp @ 2,100 rpm \\
\hline Rated torque & $405 \mathrm{lb}$-ft @ 3,250 rpm & 900 lb-ft @ 2,100 rpm \\
\hline Emissions equipment & Ford 3 way catalyst & Johnson-Matthey CRT-2124 \\
\hline Retarder/regenerative braking & Regenerative braking & Engine braking \\
\hline Air Conditioning Type & $\begin{array}{l}\text { Sutrak ACE219 Rear Mount } \\
\text { Unit (electric) }\end{array}$ & Thermo King (engine driven) \\
\hline Fuel capacity & 110 gallons & 119 gallons \\
\hline Bus purchase cost (\$) & 462,379 & 268,051 \\
\hline
\end{tabular}

${ }^{*}$ Costs listed in the table are actual costs at the time of purchase.

\section{Emissions}

Original funding for the gasoline hybrid system was provided by the US DOT/FTA, the State of California, WestStart-CALSTART, Omnitrans, and ISE.

The ThunderVolt gasoline hybrid system was certified by CARB to $0.6 \mathrm{~g} / \mathrm{bHp}-\mathrm{hr}$ NOx and 3.7g CO; PM is not measured on gasoline systems; making it a very low emission 40 -foot bus drive system. The gasoline hybrid system combines the Siemens ELFA electric drive system with the Ford ULEV rated 6.8 L V10 engine, integrated and controlled by the ISE ThunderCan hybrid control system. Table 4 below compares the emissions certification levels for the Hybrid and Diesel buses. Tailpipe emissions test results are not available for comparison. See http://www.arb.ca.gov/msprog/onroad/cert/cert.php\#6 $\mathrm{HDE} / \mathrm{HDV} / \mathrm{MDE}$ for model years 2004 and 2005.

Table 4. Hybrid and Diesel Bus Emissions Certification

\begin{tabular}{|l|l|l|l|}
\hline Study Group & $\begin{array}{l}\text { NOx } \\
\text { (g/bHp-hr) }\end{array}$ & $\begin{array}{l}\text { PM } \\
\text { (g/bHp-hr) }\end{array}$ & $\begin{array}{l}\text { CO } \\
\text { (g/bHp-hr) }\end{array}$ \\
\hline Hybrid & 0.6 & N/A & 3.7 \\
\hline Diesel & 4.0 & 0.05 & 0.5 \\
\hline
\end{tabular}

\section{Evaluation Results}

\section{Bus Use}

Table 5 presents the average monthly mileage per bus during the evaluation period for the two groups of buses. The hybrids had a usage rate $2.4 \%$ lower than that of the diesel buses. If the July ramp-up is removed from the hybrid group average their usage rate would only be $0.7 \%$ lower than the diesels. These small differences are not statistically significant (two-tailed $P$ value $=0.3455)$ and make the 
groups ideal for comparison. This monthly mileage is also an indication of both the diesel and hybrid bus reliability. The hybrids were able to provide a similar number of miles of service per month as the conventional diesels operating on similar routes.

Table 5. Average Bus Miles Driven per Month by Study Group

\begin{tabular}{|l|c|}
\hline Study Group & Average Miles per Month per Bus \\
\hline Hybrid & 3,188 \\
\hline Diesel & 3,266 \\
\hline
\end{tabular}

Figure 3 shows average monthly miles per bus for each bus group with $+/-95 \%$ confidence interval lines. Bus average usage did not change significantly during the evaluation period. This chart also shows a quick ramp-up of miles per month for the hybrids as they were implemented into the fleet in July of 2005. After this initial ramp-up, the hybrids were driven a similar number of miles for the rest of the evaluation period.

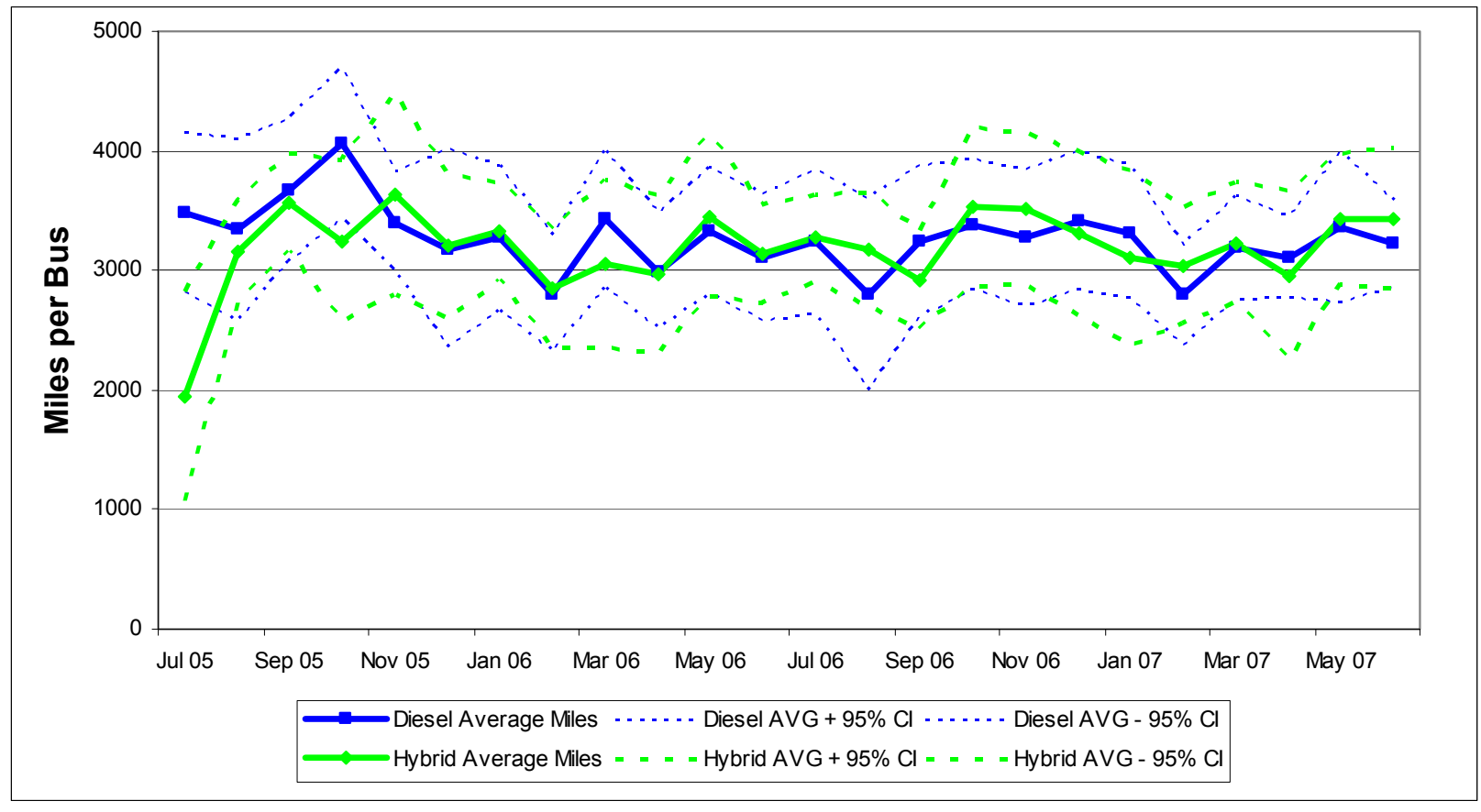

Figure 3. Hybrid gasoline-electric and diesel monthly mileage per bus.

\section{Fuel Economy and Cost}

LBT fuels its hybrids with standard California reformulated 87 octane gasoline. During the evaluation period, gasoline at LBT cost an average of \$2.49 per gallon. LBT diesel buses use ultra-low sulfur No. 1 diesel fuel at less than 30 parts per million (ppm) sulfur content. This sulfur level was required to be less than $15 \mathrm{ppm}$ by the end of 2006. During the evaluation period, diesel fuel at LBT cost an average of $\$ 2.29$ per gallon for ultra-low sulfur diesel (ULSD) fuel with sulfur less than $30 \mathrm{ppm}$.

Table 6 shows the fuel consumption and economy data for each bus in each study group. The 24-month average fuel economy for the hybrid buses is $4.3 \%$ lower than that of the diesel buses (two-tailed $\mathrm{P}$ value $=0.0001$ ). This statistically significant difference is likely due to the lower efficiency of a 
throttled, spark-ignited engine and a lower energy content per gallon of fuel. Since California reformulated gasoline has a lower energy content on a per gallon basis than diesel $(113,824 \mathrm{Btu} / \mathrm{gal}$ vs $128,450 \mathrm{btu} / \mathrm{gal}$ ), the fuel efficiency of the buses can also be looked at from an energy equivalent basis. Adjusting for this difference in volumetric energy content, the hybrid buses delivered 3.78 miles per diesel gallon equivalent; $8.0 \%$ higher than the diesels (two-tailed $\mathrm{P}$ value $<0.0001$ ).

Table 6. Hybrid and Diesel Bus Fuel Use and Economy

\begin{tabular}{|c|r|r|r|c|c|c|}
\hline Bus & Mileage & $\begin{array}{c}\text { Gallons } \\
\text { Consumed }\end{array}$ & $\begin{array}{c}\text { Miles per } \\
\text { Gallon }\end{array}$ & $\begin{array}{c}\text { Miles per } \\
\text { Diesel Gallon } \\
\text { Equivalent }\end{array}$ & $\begin{array}{c}\text { Fuel } \\
\text { Cost/Gallon (\$) }\end{array}$ & $\begin{array}{c}\text { Fuel } \\
\text { Cost/Mile (\$) }\end{array}$ \\
\hline 2402 & 67,167 & 21,521 & 3.12 & 3.52 & $\$ 2.49$ & 0.80 \\
\hline 2404 & 84,224 & 26,577 & 3.17 & 3.58 & $\$ 2.49$ & 0.79 \\
\hline 2407 & 96,767 & 27,909 & 3.47 & 3.91 & $\$ 2.49$ & 0.71 \\
\hline 2412 & 58,127 & 18,114 & 3.21 & 3.62 & $\$ 2.49$ & 0.78 \\
\hline 2414 & 95,211 & 27,218 & 3.50 & 3.95 & $\$ 2.49$ & 0.71 \\
\hline 2421 & 60,704 & 18,713 & 3.24 & 3.66 & $\$ 2.49$ & 0.77 \\
\hline 2503 & 68,352 & 19,524 & 3.50 & 3.95 & $\$ 2.49$ & 0.70 \\
\hline 2512 & 80,110 & 23,551 & 3.40 & 3.84 & $\$ 2.49$ & 0.72 \\
\hline 2514 & 71,948 & 21,139 & 3.40 & 3.84 & $\$ 2.49$ & 0.73 \\
\hline 2519 & 82,389 & 23,904 & 3.45 & 3.89 & $\$ 2.49$ & 0.72 \\
\hline Hybrid Total & $\mathbf{7 6 4 , 9 9 9}$ & $\mathbf{2 2 8 , 1 7 1}$ & $\mathbf{3 . 3 5}$ & $\mathbf{3 . 7 8}$ & $\$ 2.49$ & $\mathbf{0 . 7 4}$ \\
\hline 2202 & 50,933 & 14,411 & 3.53 & $\mathrm{~N} / \mathrm{A}$ & $\$ 2.29$ & 0.65 \\
\hline 2204 & 88,107 & 24,799 & 3.55 & $\mathrm{~N} / \mathrm{A}$ & $\$ 2.29$ & 0.65 \\
\hline 2206 & 67,684 & 19,054 & 3.55 & $\mathrm{~N} / \mathrm{A}$ & $\$ 2.29$ & 0.64 \\
\hline 2208 & 65,167 & 18,506 & 3.52 & $\mathrm{~N} / \mathrm{A}$ & $\$ 2.29$ & 0.65 \\
\hline 2210 & 72,626 & 21,171 & 3.43 & $\mathrm{~N} / \mathrm{A}$ & $\$ 2.29$ & 0.67 \\
\hline 2212 & 90,865 & 25,622 & 3.55 & $\mathrm{~N} / \mathrm{A}$ & $\$ 2.29$ & 0.65 \\
\hline 2216 & 99,216 & 27,742 & 3.58 & $\mathrm{~N} / \mathrm{A}$ & $\$ 2.29$ & 0.64 \\
\hline 2218 & 91,911 & 26,499 & 3.47 & $\mathrm{~N} / \mathrm{A}$ & $\$ 2.29$ & 0.66 \\
\hline 2225 & 93,363 & 27,162 & 3.44 & $\mathrm{~N} / \mathrm{A}$ & $\$ 2.29$ & 0.67 \\
\hline 2226 & 63,977 & 18,797 & 3.40 & $\mathrm{~N} / \mathrm{A}$ & $\$ 2.29$ & 0.67 \\
\hline Diesel Total & $\mathbf{7 8 3 , 8 4 9}$ & $\mathbf{2 2 3 , 7 6 1}$ & $\mathbf{3 . 5 0}$ & $\mathrm{N} / \mathrm{A}$ & $\$ 2.29$ & $\mathbf{0 . 6 5}$ \\
\hline
\end{tabular}

Figure 4 shows the average monthly mpg for each bus group with $+/-95 \%$ confidence interval lines. 


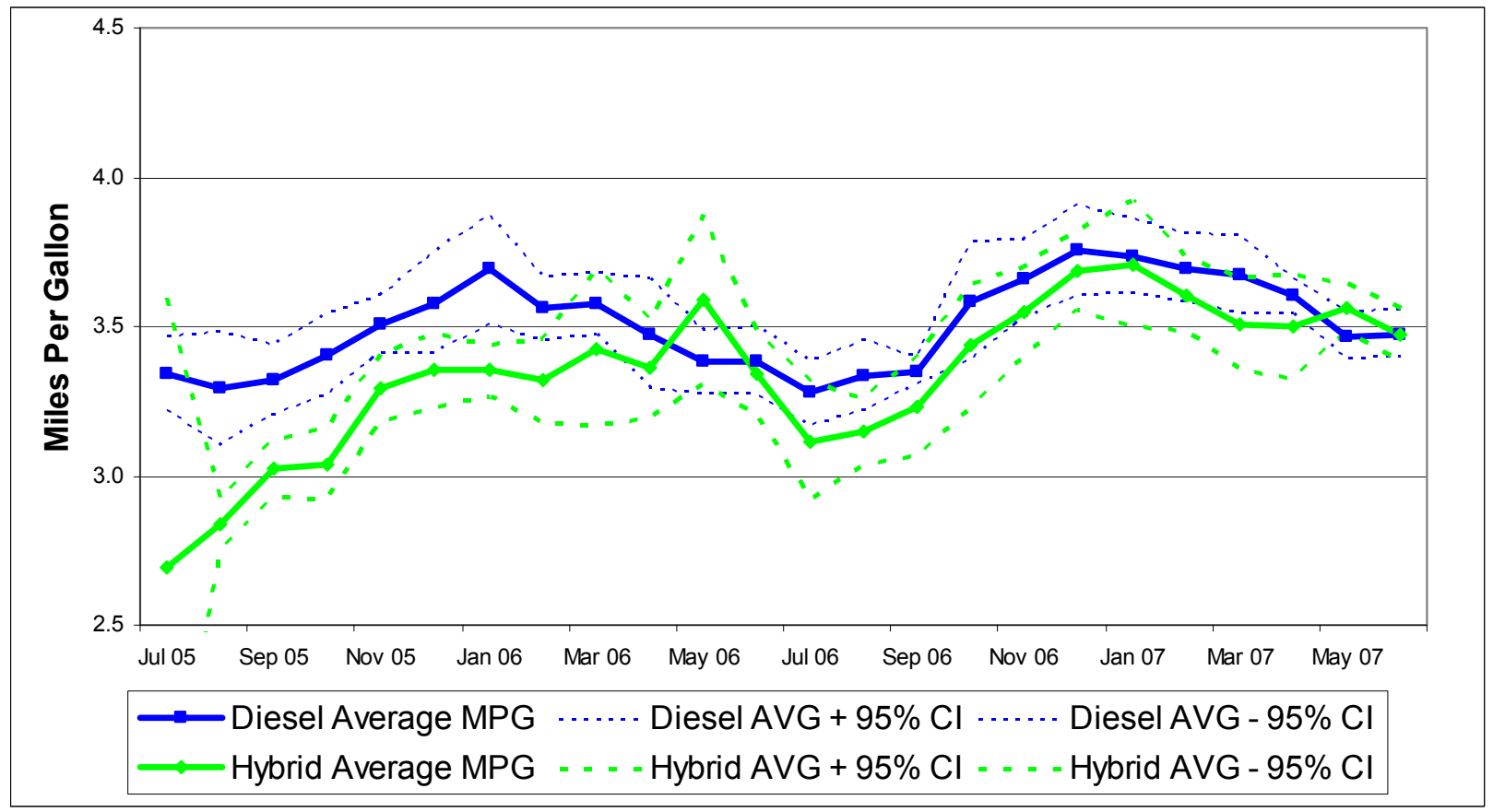

Figure 4. Average monthly fuel economy.

Figure 5 shows the average monthly energy equivalent mpg for each bus group with $+/-95 \%$ confidence interval lines.

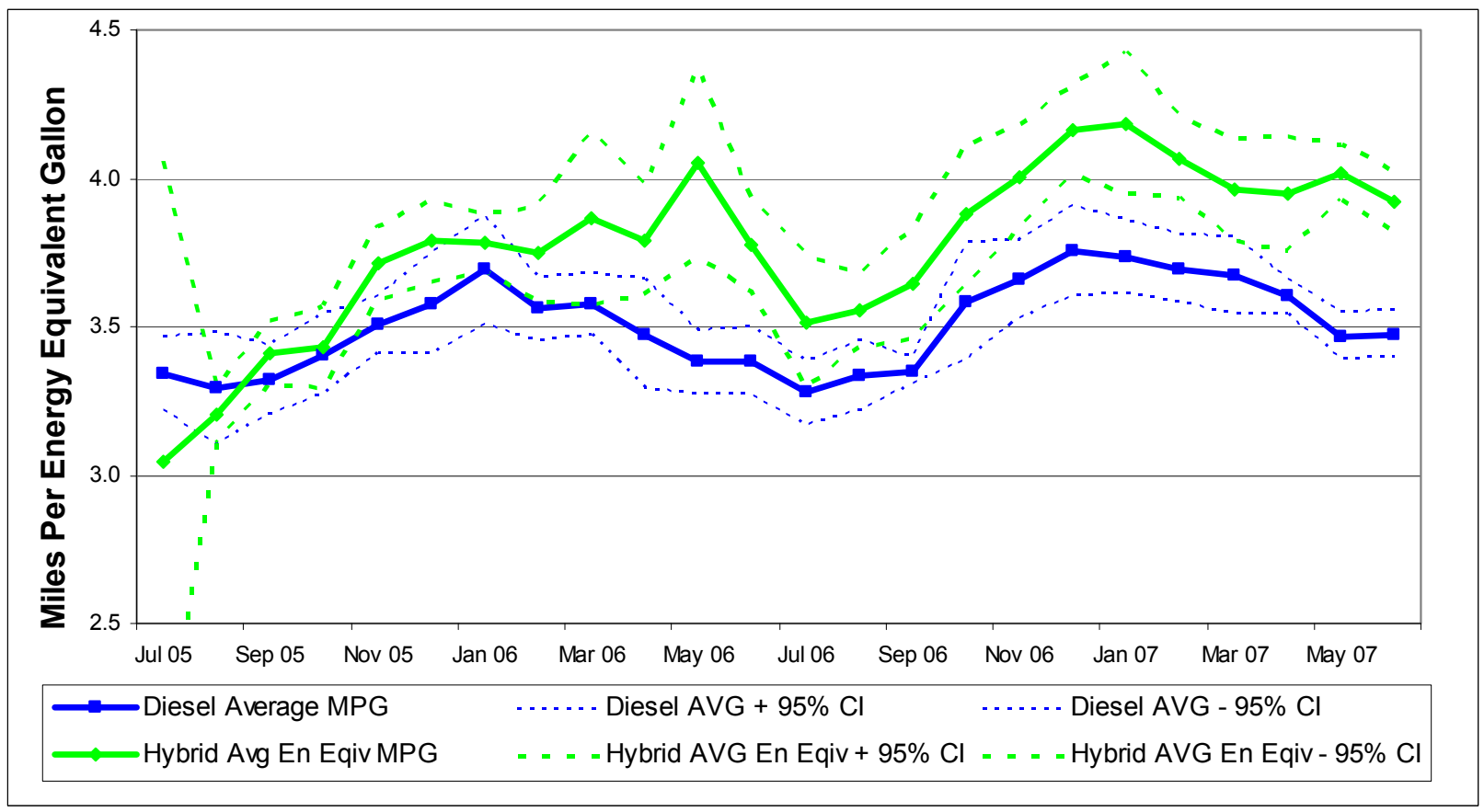

Figure 5. Average monthly energy equivalent fuel economy.

Figures 4 and 5 also showcase the seasonal fluctuation in fuel economy experienced by both hybrid and diesel buses during the 24-month evaluation period. Comparing the summer months of 2006 (June, July, 
August) to the winter months of 2006-2007 (December, January, February) the diesels had statistically significant $10.2 \%$ lower fuel economy in the summer (two-tailed $\mathrm{P}$ value $=0.0123$ ) and the hybrids had statistically significant $12.8 \%$ lower fuel economy in the summer (two-tailed $\mathrm{P}$ value $=0.0259$ ). Much of the summer decrease is caused by an increase in energy consumption for air conditioning; it is not clear why the hybrids experience a greater drop in fuel economy. The hybrids do have electric air conditioning, but this was not isolated as a benefit or detriment to the overall fuel economy.

\section{Maintenance Cost Analysis}

This evaluation focuses on bus operations spanning the first two years of the 12-year minimum life of a transit bus. This short evaluation period does not yield enough capital and operating costs to allow us to understand the full 12-year life-cycle cost of the hybrid buses. To gain a complete understanding of costs, we must examine the purchase cost of the buses and the costs for facility modification or addition, warranty, and operations. In addition, we must consider costs for longer term maintenance activities such as engine rebuilds or replacements and ultra-capacitor replacements. Finally, we must look at areas where cost savings can be achieved, as in brake repair. The intent of this evaluation, though, is to capture accurate actual capital and known operations costs associated with the hybrid and diesel vehicles for the time period selected. This analysis is not predictive of maintenance costs assumed by the transit agency beyond the warranty period. ISE's standard propulsion system warranty on these hybrids is two years from the date of purchase and includes the ultra-capacitors. LBT opted to purchase three years of extended propulsion system warranty for the first 27 buses and use the standard two-year warranty for the remaining 20 buses. Some propulsion system components are warranted beyond two years. Hybrid buses in the study group fall into both warranty categories, but all remained under warranty for the entire study period. The exact components and warranty periods, as negotiated by LBT, ISE, and New Flyer, are contractual.

The hybrid buses are new enough that much of the maintenance is done under warranty. All maintenance for the ISE hybrid drive was done on site by ISE mechanics. These maintenance costs are not included in the maintenance cost analysis in this section. Not accounting for warranty repairs in the evaluation of total maintenance cost does offer an incomplete picture of total maintenance cost. Even with warranty costs absent, however, this analysis reflects the actual cost to the transit agency during the time period selected.

The FT\&E team collected the maintenance costs in the same way for each study group. The duty cycle and maintenance practices are the same for both diesel and hybrid study groups. All work orders and parts information available were collected for the study buses. The maintenance analysis discussions include only maintenance data from the evaluation period on the study group buses.

Two major interests in hybrid bus operations held by the transit industry are (1) determining energy storage replacement frequency and costs, and (2) quantifying the benefits of regenerative braking. In addition, the benefits of regenerative braking, realized in reduced maintenance costs, are evaluated using data from the hybrid buses. Diesel buses are used as a baseline in this evaluation. 


\section{Total Maintenance Costs}

This cost category includes the costs of parts and hourly labor costs of $\$ 50$ per hour, and does not include warranty costs. Cost per mile is calculated as follows:

$$
\text { Cost per mile }=((\text { labor hours } * 50)+\text { parts cost }) / \text { mileage }
$$

The labor rate has been artificially set at a constant rate of $\$ 50$ per hour so that other analysts can change this rate to one more similar to their own. This rate does not directly reflect LBT's current hourly mechanic rate.

Table 7 shows total and propulsion related maintenance costs for the two study groups. The total maintenance cost per mile was $42 \%$ less for the hybrid buses than for the diesel buses. At the beginning of the evaluation period, the hybrid buses were brand new and remained under warranty for the evaluation period, which accounts for the cost-per-mile difference with the older, out-of-warranty diesel buses.

Table 7. Hybrid and Diesel Bus Total \& Propulsion Maintenance Costs

\begin{tabular}{|l|l|c|c|c|}
\hline Study Group & Miles & Parts Cost & Labor Hours & Cost per Mile (\$/mile) \\
\hline Hybrid & 764,999 & $\$ 56,664$ & 3,646 & 0.3124 \\
\hline Hybrid Propulsion-Related & 764,999 & $\$ 15,050$ & 8,96 & 0.0782 \\
\hline Diesel & 783,849 & $\$ 137,287$ & 5,707 & 0.5392 \\
\hline Diesel Propulsion-Related & 783,849 & $\$ 62,508$ & 1,739 & 0.1906 \\
\hline
\end{tabular}

\section{Propulsion-Related Maintenance Costs}

The propulsion-related vehicle systems include the exhaust; fuel; engine, nonlighting electrical (general electrical, charging, cranking, and ignition); electric propulsion; and transmission systems. The ultracapacitors are discussed in the next section of this report. Table 8 summarizes the cost comparisons between the study groups.

Table 8. Summary of Propulsion-Related Maintenance Cost Comparisons

\begin{tabular}{|l|l|l|}
\hline Vehicle System & $\begin{array}{l}\text { Hybrid } \\
\mathbf{( \$ / m i l e )}\end{array}$ & $\begin{array}{l}\text { Diesel } \\
\mathbf{( \$ / m i l e )}\end{array}$ \\
\hline Exhaust system & 0.0059 & 0.0220 \\
\hline Fuel system & 0.0051 & 0.0193 \\
\hline Engine & 0.0392 & 0.0844 \\
\hline Non-lighting electrical & 0.0176 & 0.0267 \\
\hline Transmission & $\mathrm{N} / \mathrm{A}$ & 0.0382 \\
\hline Total propulsion-related & $\mathbf{0 . 0 7 8 2}$ & $\mathbf{0 . 1 9 0 6}$ \\
\hline
\end{tabular}

Figure 6 shows the cumulative average total and propulsion-related maintenance cost per mile for the study buses. Figure 7 shows the monthly average total and propulsion-related maintenance cost per mile for the study buses. 


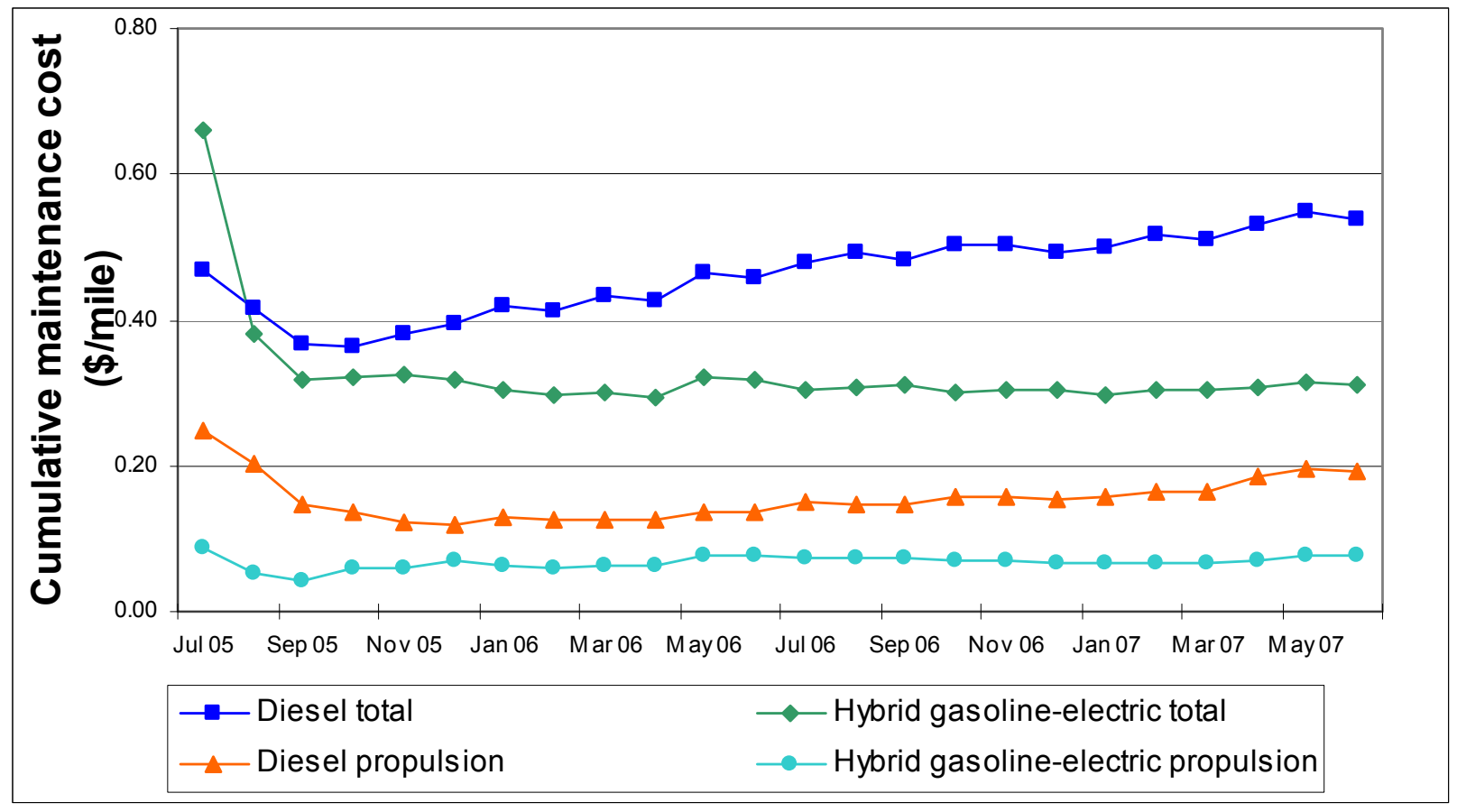

Figure 6. Cumulative total and propulsion-related maintenance costs.

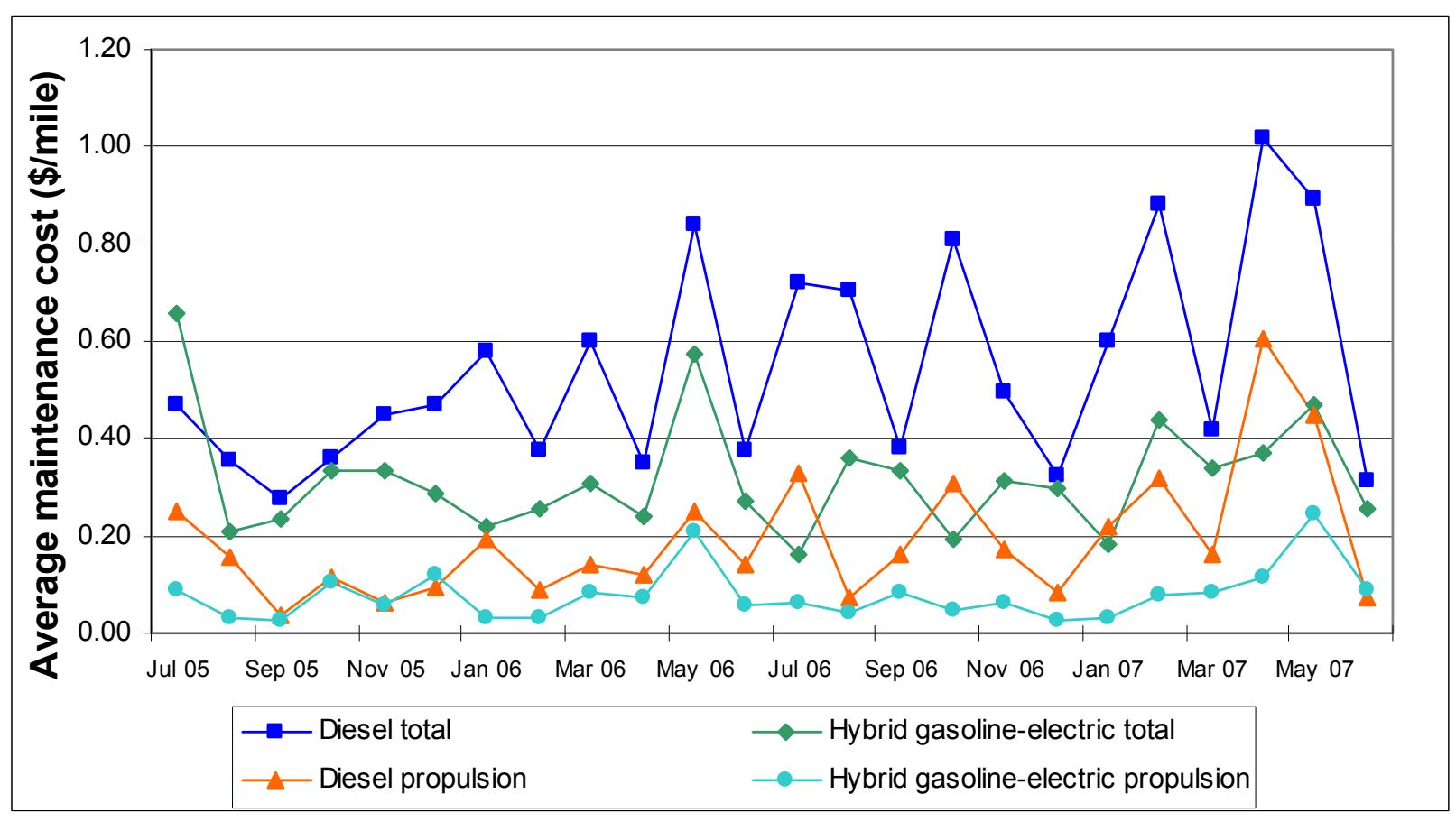

Figure 7. Average monthly total and propulsion-related maintenance costs.

\section{Brakes}

In general, the brake system maintenance costs are expected to be dramatically lower for hybrid propulsion systems with regenerative braking, which allows use of the electric drive motors to slow a bus, similar to a transmission retarder. The energy from braking is taken into the electric motor and then fed back to the ultra-capacitors. In addition, the ISE system incorporates additional "braking resistors" to 
absorb energy when the ultra-capacitors are fully charged. LBT's staff expects diesel buses to undergo a four-wheel brake reline every 35,000 to 40,000 miles on average.

Table 9 shows the maintenance costs for the brake system repairs for the two study groups. During the evaluation period, the 10 hybrid study buses traveled 764,999 miles and required only minimal brake system maintenance such as adjustments for squeaking.

Maintenance costs for the brakes on the baseline diesel buses - which had only slightly higher miles than the hybrids - were 10 times greater than the costs for the hybrids. All 10 buses in the diesel study group had at least a rear brake reline during the evaluation period. Six of the 10 had at least a four wheel reline during the study period, and some of the buses had an additional rear reline.

It is important to note that the diesel buses did not have new brakes at the beginning of the study period. The lower brake system cost assumption, however, is supported by the extent of relines and the longerthan-average miles without a reline for the hybrids during the study period.

Table 9. Brake System Maintenance Costs (July 2005-June 2007)

\begin{tabular}{|l|c|c|c|c|}
\hline Study Group & Mileage & $\begin{array}{c}\text { Parts Cost } \\
\mathbf{( \$ )}\end{array}$ & Labor Hours & $\begin{array}{c}\text { Cost per Mile } \\
\mathbf{( \$ / m i l e )}\end{array}$ \\
\hline Hybrid & 764,999 & 17.11 & 55 & 0.0036 \\
\hline Diesel & 783,849 & $11,192.94$ & 335 & 0.0356 \\
\hline
\end{tabular}

Figure 8 shows the average time to the first front and rear brake relines on the older diesel buses as compared to the average hybrid bus mileage at the end of the two-year study period. None of the hybrid buses had a reline during the study period. The first relines on the diesel buses occurred before the study period of this report, but are included here to provide an understanding of the brake life comparison. All of the hybrid buses have more miles on them than any diesel bus had by the time of its first rear reline. On average, the hybrid buses have doubled the mileage to first rear brake reline and are approaching the mileage the diesel buses averaged for their first front reline. Assuming the front brakes on the hybrids will last twice as long as the rears, as was the case for the diesels, this data suggests the hybrids will get at least twice the mileage on average between brake relines. From routine inspections, LBT anecdotally suggests they are only half of the way through the brake linings at this point. Measurements were not taken however. 


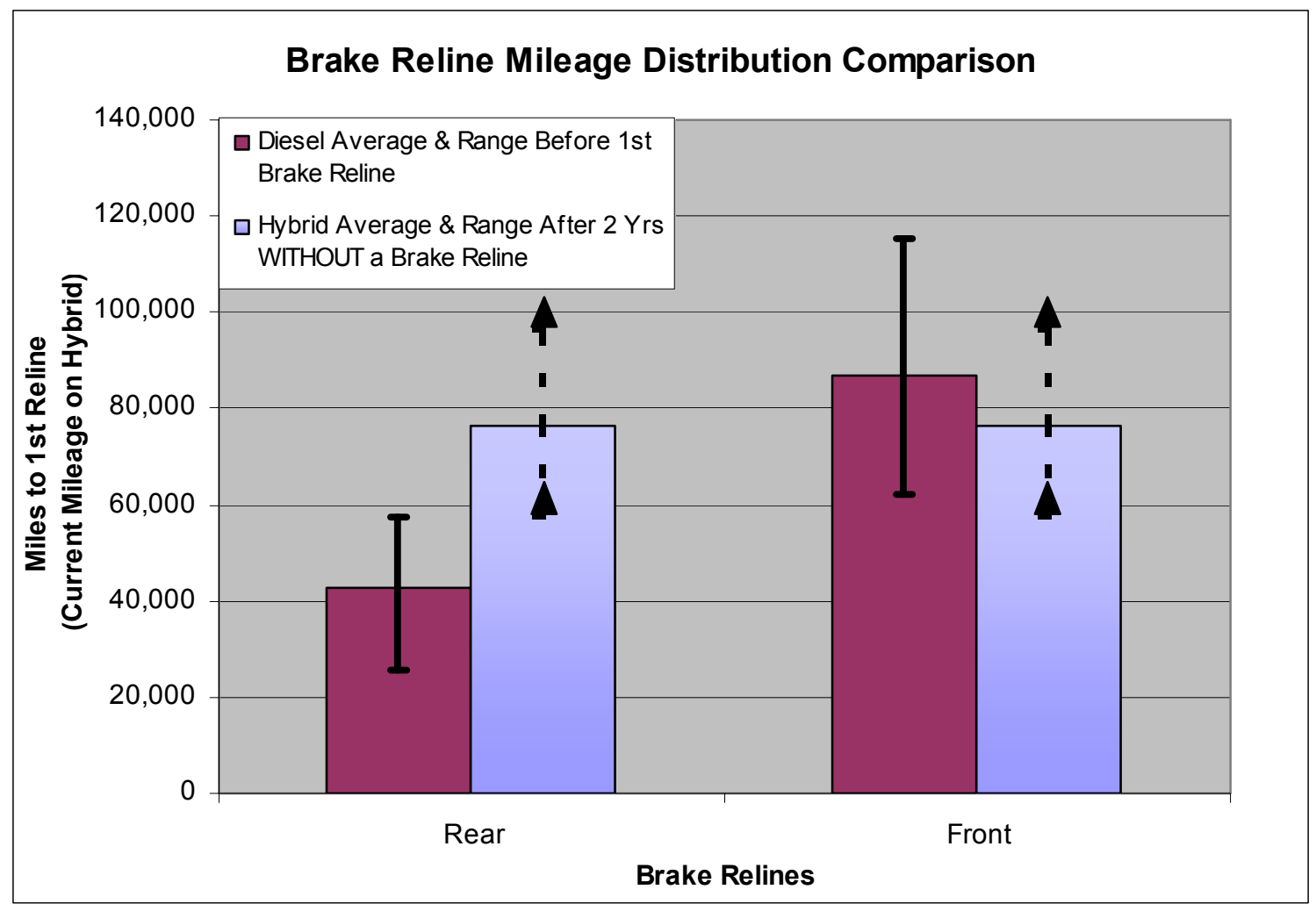

Figure 8. Brake reline mileage distribution comparison.

\section{Ultra-Capacitors}

LBT chose to use ultra-capacitors for energy storage instead of the traction batteries more commonly used in hybrid transit buses. The ultra-capacitors work well for LBT's duty cycle with the frequent stops per mile and slow average speeds. In addition, the ultra-capacitors have a 12-year life expectancy compared to three to six years for batteries. ISE has a standard two-year warranty for the ultra-capacitors and offers a three-year extension of the warranty. LBT bought the extended warranty on the first 27 buses, but not the remaining 20 .

During the evaluation period a manufacturing issue was identified; acetonitrile was leaking from some of the ultra-capacitors. ISE corrected the issue with a warranty campaign based on serial numbers of suspect batches of ultra-capacitors. The correction sealed them by applying an epoxy coating over the ultra-capacitors. Because this correction was handled as a campaign no cost was incurred to LBT and these repairs do not affect the maintenance analysis section of this report. Two incidents of ultracapacitor dry cell overheating were attributed to this leakage within the fleet. 
Figure 9 is a photo of an open ultra-capacitor pack showing the 144 individual cells. Figure 10 shows the installation of the two ultra-capacitor packs on the rear roof of the bus with the ultra-capacitor cooling system in the background.

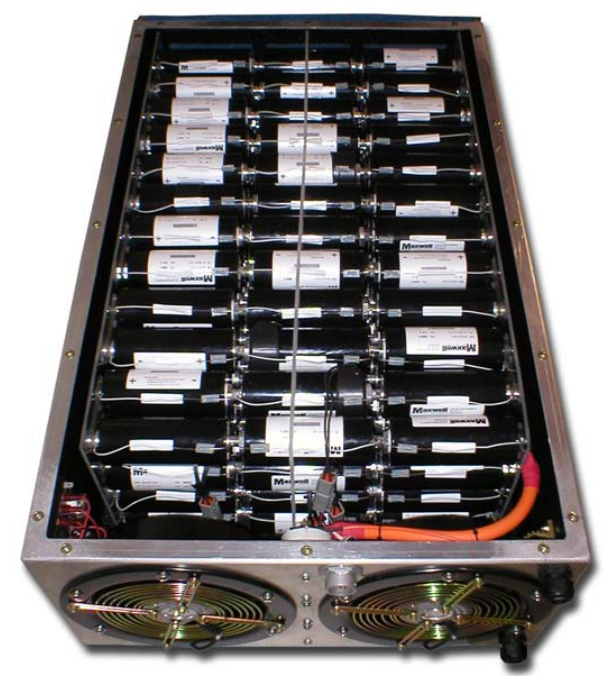

Figure 9. An Open ultra-capacitor pack.

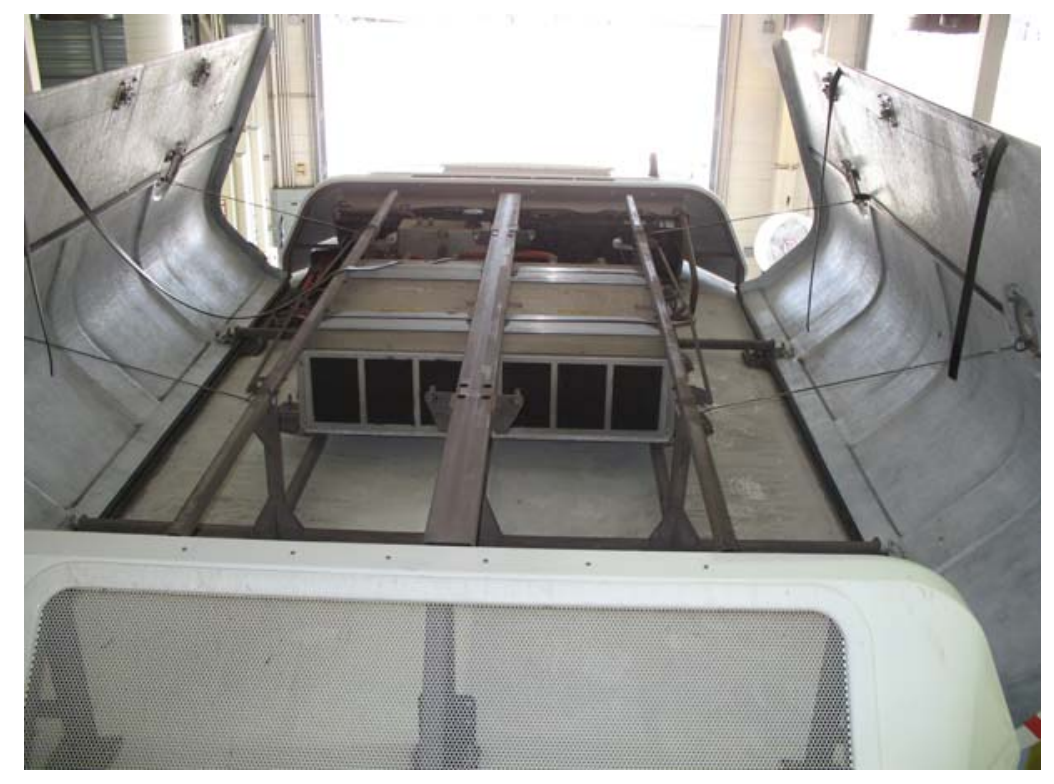

Figure 10. Two ultra-capacitor packs on the rear roof of the bus.

\section{Road Call Analysis}

Figure 11 shows the cumulative average miles between road call (MBRC) for all road calls (RCs) along with those related only to propulsion. MBRC is a good indication of the reliability of a vehicle. Propulsion-related systems include the exhaust; fuel; engine, non-lighting electrical (general electrical, charging, cranking, and ignition); electric propulsion; and transmission systems. Also note that the diesel study group had four months without a propulsion-related $\mathrm{RC}$ at the beginning of the study period. This heavily weighted the cumulative average very high, but it is clear the trend is coming back down over time to reflect propulsion MBRC similar to that of the hybrids. 


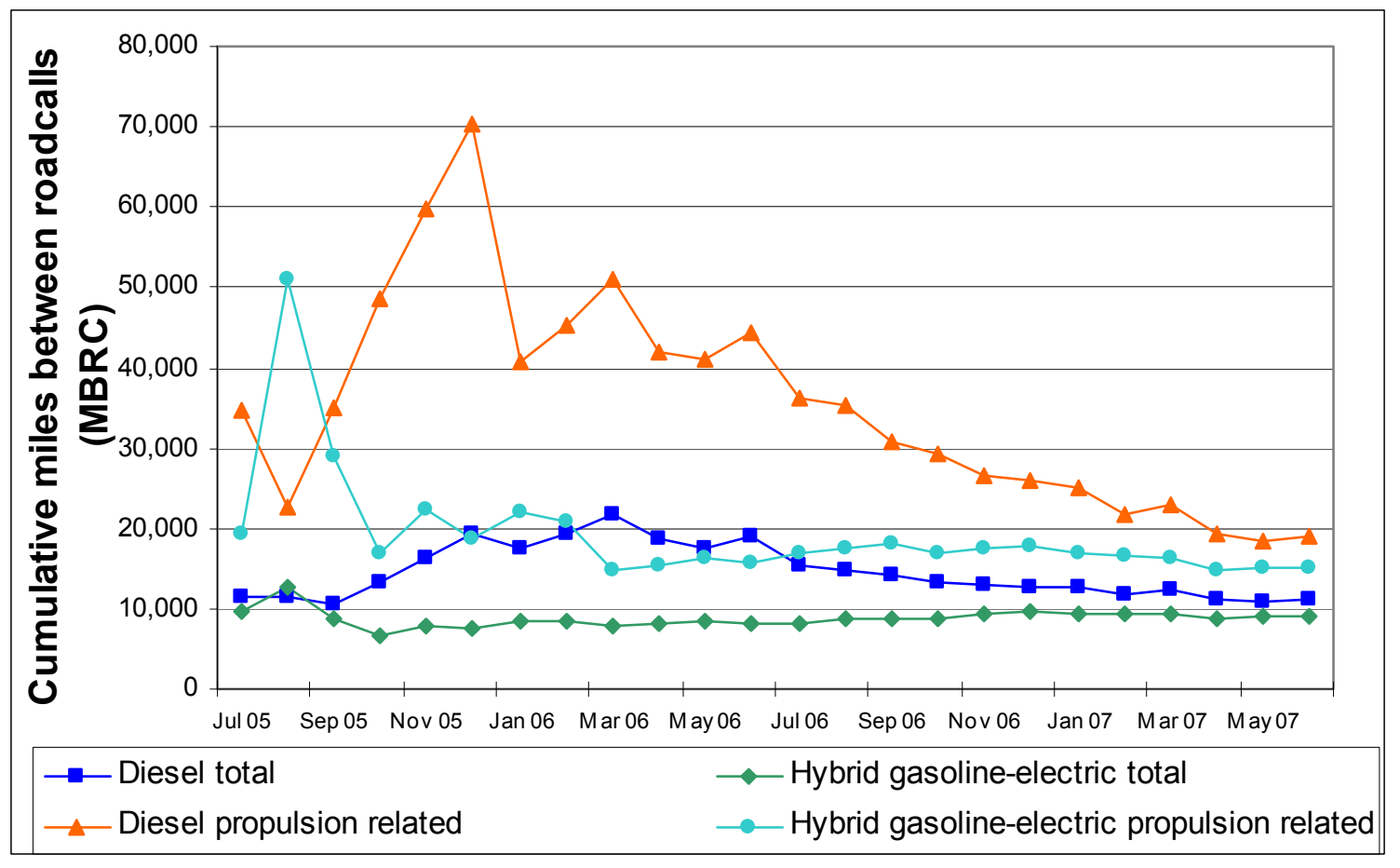

Figure 11. Cumulative miles between road call.

The diesels had 71 road calls during the study period while the hybrids had $85 ; 20 \%$ more. The diesels had 41 propulsion related road calls during the study period while the hybrids had $51 ; 24 \%$ more. LBT's fleet average is about 9,000 total MBRC. LBT had no official expectations for the hybrids because the combination of a light-duty gasoline engine in a series hybrid heavy-duty application with ultra-capacitors had never been done before. LBT's staff has been happy with the MBRC performance of the hybrids, shown in comparison to that of the diesels in Table 10.

Table 10. Cumulative Miles Between Road Call Comparison

\begin{tabular}{|c|c|c|c|c|c|}
\hline $\begin{array}{c}\text { Study } \\
\text { Group }\end{array}$ & Miles & $\begin{array}{c}\text { Total } \\
\text { Road Calls }\end{array}$ & $\begin{array}{c}\text { Total } \\
\text { MBRC }\end{array}$ & $\begin{array}{c}\text { Propulsion } \\
\text { Road Calls }\end{array}$ & $\begin{array}{c}\text { Propulsion } \\
\text { MBRC }\end{array}$ \\
\hline Hybrid $^{*}$ & 764,999 & 85 & 9,000 & 51 & 15,000 \\
\hline Diesel & 783,849 & 71 & 11,040 & 41 & 19,118 \\
\hline
\end{tabular}

* hybrid MBRC happened to result in even numbers.

\section{Summary of Costs}

Table 11 summarizes fuel and maintenance cost per mile for the two study groups. The average cost per mile for the hybrid buses is $11.7 \%$ lower than that of the diesel buses because the hybrids have the majority of their maintenance costs covered under warranty and the diesel buses are not. 
Table 11. Summary of Costs per Mile

\begin{tabular}{|c|c|c|c|}
\hline Bus & $\begin{array}{c}\text { Fuel } \\
\text { Cost/Mile (\$) }\end{array}$ & $\begin{array}{c}\text { Maintenance } \\
\text { Cost/Mile (\$) }\end{array}$ & $\begin{array}{c}\text { Total } \\
\text { Cost/Mile (\$) }\end{array}$ \\
\hline 2402 & 0.80 & 0.24 & 1.04 \\
\hline 2404 & 0.79 & 0.84 & 1.63 \\
\hline 2407 & 0.71 & 0.23 & 0.94 \\
\hline 2412 & 0.78 & 0.23 & 1.01 \\
\hline 2414 & 0.71 & 0.27 & 0.97 \\
\hline 2421 & 0.77 & 0.29 & 1.06 \\
\hline 2503 & 0.70 & 0.18 & 0.88 \\
\hline 2512 & 0.72 & 0.31 & 1.03 \\
\hline 2514 & 0.73 & 0.25 & 0.98 \\
\hline 2519 & 0.72 & 0.23 & 0.96 \\
\hline Hybrid Total & $\mathbf{0 . 7 4}$ & $\mathbf{0 . 3 1}$ & $\mathbf{1 . 0 5}$ \\
\hline 2202 & 0.65 & 0.75 & 1.40 \\
\hline 2204 & 0.65 & 0.80 & 1.44 \\
\hline 2206 & 0.64 & 0.46 & 1.10 \\
\hline 2208 & 0.65 & 0.70 & 1.34 \\
\hline 2210 & 0.67 & 0.37 & 1.04 \\
\hline 2212 & 0.65 & 0.39 & 1.04 \\
\hline 2216 & 0.64 & 0.53 & 1.17 \\
\hline 2218 & 0.66 & 0.47 & 1.13 \\
\hline 2225 & 0.67 & 0.48 & 1.15 \\
\hline 2226 & 0.67 & 0.53 & 1.20 \\
\hline Diesel Total & $\mathbf{0 . 6 5}$ & $\mathbf{0 . 5 4}$ & $\mathbf{1 . 1 9}$ \\
\hline
\end{tabular}

\section{Status of LBT Hybrid Fleet}

LBT has been happy with the performance of the original forty-seven 40-ft hybrid gasoline-electric buses over the first two years of service. The transit authority has taken delivery of 15 more in the third quarter of 2007 and has requested an additional 25 for 2008.

\section{Conclusions}

- Monthly miles per bus were essentially the same with the hybrids as with the diesels. This usage rate is one indication of reliability.

- Fuel economy on a mpg basis was $4.3 \%$ lower than the diesel buses and fuel costs for gasoline were higher than diesel resulting in a higher fuel cost per mile. On an energy equivalent basis the hybrids had $8.5 \%$ better fuel economy than the diesels.

- Maintenance costs were lower on the hybrids, but they are under warranty while the diesel buses are not.

- Brake costs per mile were much lower on the hybrid bus group. The hybrid buses did not experience their first brake relines during the study period so the magnitude of the improvement could not be calculated.

- MBRC was lower for the hybrids than the diesels. This indicates a lower level of reliability. 


\section{Contacts}

\section{U.S. Department of Energy}

Energy Efficiency and Renewable Energy

Vehicle Technologies Program

Lee Slezak

Manager, Advanced Vehicle Testing Activity

Phone: 202-586-2335

E-mail: lee.slezak@ee.doe.gov

National Renewable Energy Laboratory

Mike Lammert

Project Engineer

Phone: 303-275-4067

E-mail: michael_lammert@nrel.gov

\section{Long Beach Transit}

Rolando Cruz

Manager, Maintenance

Phone: 562-599-8506

E-mail: $\underline{\text { rcruz@lbtransit.com }}$

\section{ISE Corporation}

Joshua Goldman

Senior Project Engineer

Phone: 858-413-1752

E-mail: jgoldman@,isecorp.com

\section{Battelle}

Kevin Chandler

Principal Research Scientist

Phone: 614-424-5127

E-mail: chandlek@,battelle.org 


\section{References and Related Reports}

\section{LBT Related Reports}

ARB (2002). Proposed Modifications to the Public Transit Bus Fleet Rule and Interim Certification Procedures for Hybrid-Electric Urban Transit Buses. Staff Report: Initial Statement of Reasons.

Chandler, K.; Clark, N.; Zhen, F.; Wayne, S. (2007). "Hybrid-Electric Transit Bus Performance in North America." Transportation Research Board Annual Meeting 2007. Paper \#07-3004. 


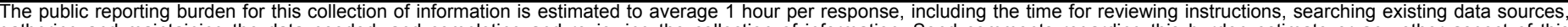

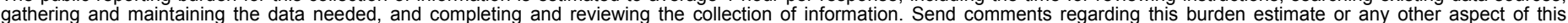

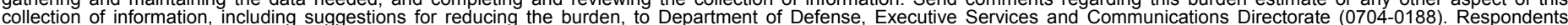

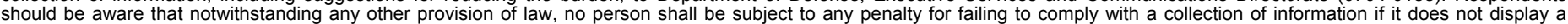

currently valid OMB control number

PLEASE DO NOT RETURN YOUR FORM TO THE ABOVE ORGANIZATION.

\begin{tabular}{l|l|l|l} 
1. REPORT DATE $(D D-M M-Y Y Y Y)$ & 2. REPORT TYPE & 3. DATES COVERED (FrOm - TO)
\end{tabular} June 2008

TP Techical Paper

4. TITLE AND SUBTITLE

Long Beach Transit: Two-Year Evaluation of Gasoline-Electric

Hybrid Transit Buses 5a. CONTRACT NUMBER

DE-AC36-99-G010337

5b. GRANT NUMBER

5c. PROGRAM ELEMENT NUMBER

5d. PROJECT NUMBER

NREL/TP-540-42226

5e. TASK NUMBER

FC08.3000

5f. WORK UNIT NUMBER
7. PERFORMING ORGANIZATION NAME(S) AND ADDRESS(ES)

National Renewable Energy Laboratory

1617 Cole Blvd.

Golden, CO 80401-3393
8. PERFORMING ORGANIZATION REPORT NUMBER

NREL/TP-540-42226

9. SPONSORING/MONITORING AGENCY NAME(S) AND ADDRESS(ES)

10. SPONSOR/MONITOR'S ACRONYM(S) NREL

11. SPONSORING/MONITORING AGENCY REPORT NUMBER

12. DISTRIBUTION AVAILABILITY STATEMENT

National Technical Information Service

U.S. Department of Commerce

5285 Port Royal Road

Springfield, VA 22161

13. SUPPLEMENTARY NOTES

14. ABSTRACT (Maximum 200 Words)

This report focuses on a gasoline-electric hybrid transit bus propulsion system. The propulsion system is an alternative to standard diesel buses and allows for reductions in emissions (usually focused on reductions of particulate matter and oxides of nitrogen) and petroleum use. Gasoline propulsion is an alternative to diesel fuel and hybrid propulsion allows for increased fuel economy, which ultimately results in reduced petroleum use.

15. SUBJECT TERMS

hybrid transit bus; Long Beach Transit; ultra-capacitors; diesel bus; LBT

\begin{tabular}{|c|c|c|}
\hline $\begin{array}{l}\text { a. REPORT } \\
\text { Unclassified }\end{array}$ & $\begin{array}{l}\text { b. ABSTRACT } \\
\text { Unclassified }\end{array}$ & $\begin{array}{l}\text { c. THIS PAGE } \\
\text { Unclassified }\end{array}$ \\
\hline
\end{tabular}

\begin{tabular}{|c|c|}
\hline $\begin{array}{l}\text { 7. LIMITATION } \\
\text { OF ABSTRACT }\end{array}$ & $\begin{array}{l}\text { 18. NUMBER } \\
\text { OF PAGES }\end{array}$ \\
\hline UL & \\
\hline
\end{tabular}

19a. NAME OF RESPONSIBLE PERSON

19b. TELEPHONE NUMBER (Include area code) 